\title{
PUBLIC FOOD PROCUREMENT - THE SITUATION IN LATVIA
}

\begin{abstract}
Inita KRIVAŠONOKA, Institute of Entrepreneurship and Management, Faculty of Economics and Social Development, Latvia University of Agriculture, Liela iela 2, Jelgava, Latvia; inita.krivasonoka@gmail.com (corresponding author)

Andra ZVIRBULE, Faculty of Economics and Social Development, Latvia University of Agriculture, Liela iela 2, Jelgava, Latvia;
\end{abstract} andra.zvirbule@1lu.lv

\begin{abstract}
One of the most important medium-term tasks in Latvia is the promotion of production and consumption of local food through implementing measures aimed at increasing the market share of food products produced in Latvia in public procurement and consumption.

The research aim is to examine the situation of public food procurement in Latvia and assess the changes of local products share in public food procurement.

In Latvia, at the end of 2014, in response to Russia's embargo on the Latvian-produced food products and to promote local food consumption in the country was accepted new Regulations. These Regulations prescribe the requirements for public procurement using environmental criteria, and their application, as well as the applicable tender selection criteria for the food supply and catering contracts. This contributed an increase of the quantity of purchases where ZPP criteria were used, thereby also increased the share of local production. The purchase of food from local farmers positively affects local entrepreneurship, while providing a significant income source for the local farmers; in this way, the viability of many small local agricultural holdings is maintained.

Research methods used: monographic, descriptive, analysis, synthesis, statistical analysis. The present research was performed based on the statistical data, research papers and other information sources.
\end{abstract}

Keywords: local food, public food procurement, sustainability

\section{INTRODUCTION}

Public procurement plays an important role in the development of the regions. It is one of the market instruments to meet the needs of society and the efficient use of public funds.

According to Russell and Meehan (Russell and Meehan, 2014), public procurement's role is to ensure regulatory compliance, prudent use of the public purse, and third-party delivery of contracted goods and services.

Research by several authors (Jackson, 2010; Pringle, 2013) confirms that state and local government procurement has a very significant impact on the local economy. Purchasing by private and public sector institutions is a major force in the economy. Institutional procurement presents a large opportunity for local economic development. By purchasing goods and services from local suppliers, public and private institutions could increase local jobs and economic wealth.

Government procurement contracts are a significant part of many economies. Government is the largest single buyer of goods and services in most economies, with expenditures by governments often amounting to $20 \%$ to $30 \%$ of GDP (Tewes-Gradl et al., 2013).

Food as well as the food industry plays a vitally essential role in meeting the needs of consumers. The food industry comprises $2 \%$ of the EU gross domestic product (GDP) and employs $13.5 \%$ of the workforce in the EU manufacturing sector. Europe's largest revenues are gained from food manufacturing. In Europe, about 310000 enterprises are engaged in the food industry, of which $99 \%$ are small and medium enterprises, and its contribution to the EU economy totals EUR 600 billion (Manzini and Accorsi, 2012). The food industry as one of the largest economic sectors in Latvia is of great importance to economic growth as well.

In recent years, attention has been paid in all EU Member States to improving the public procurement system and restoring the legal framework. The European Commission has launched various activities since 2010. Legislative measures included the revision of the public procurement directives and the inclusion of specific provisions relating to public procurement systems, such as environmental protection and energy efficiency requirements, in partnership agreements to be implemented by the Member States by the end of 2016 at the latest.

The introduction of a new regulatory framework for public procurement is determined by Directive 2014/24 / EU of the European Parliament and of the Council of 26 February 2014 on public procurement and which is repealing Directive 2004/18/EC, which aims to modernize and specify existing public procurement rules, also taking into account 
the case-law of the European Court of Justice on public procurement and its developed understanding of the content of the previous directive; and Directive 2014/25/EU on procurement by entities operating in the water, energy, transport and postal services sectors and which is repealing Directive 2004/17/EC, which lays down similar provisions for the inclusion of environmental criteria in public procurement, as well as complements the current regulatory framework, including a detailed regulation for life cycle costing.

In recent years both in the world and in Latvia, focus has been placed on consuming food as close to its production site as possible, i.e. local food. According to a number of authors (Adams and Salois, 2010, Knight, 2011), the demand for local products rises, and expressing belonging to a local area is one of the latest trends on the global food market.

The purchase of food from local farmers positively affects local entrepreneurship, while providing a significant income source for the local farmers; in this way, the viability of many small local agricultural holdings is maintained. Consequently, the emphasis on procurement is placed on the implementation of GPP criteria in procurement.

According to the European Commission (What is GPP, 2014), each year, EU Member States spend on average $19 \%$ of GDP on public procurement. Public procurements in Latvia amount to 17\% of GDP (Green Public Procurement.., 2015). Such an impact on the market for goods and services is important, therefore, including environmental requirements in public procurement (through green public procurement), it is possible not only to promote the growth of the share of environmentally friendly goods and services in the market, but also to achieve financial and social improvements (environment friendly procurement). In the Portugal it is estimated that savings of more than EUR 155 million for the period 2009-2012, with 269 qualified suppliers, for a total of EUR 1 billion annual public expenditure was achieved through smart procurement which included GPP (Going green..., 2014).

The research aim is to examine the situation of public food procurement in Latvia and assess the changes of local products share in public food procurement.

\section{MATERIALS AND METHODS}

Research methods used: monographic, descriptive, analysis, synthesis, statistical analysis. The present research was performed based on the statistical data, research papers and other information sources.

\section{RESEARCH RESULTS}

\section{Public procurement policy and normative base in Latvia}

In Latvia, the Ministry of Finance is responsible for the development of state policy in the field of public procurement and, in cooperation with the institution under its supervision, the Procurement Monitoring Bureau it carries out the implementation of this policy.

The purpose of public procurement policy is to ensure that the use of funds of procurers and public service providers, is respecting principles such as transparency, efficiency, fair competition and equal treatment of market participants, thereby reducing the risk of fraud and corruption.

Accordingly to Procurement Monitoring Bureau Statutes (Procurement Monitoring Bureau..., 2013) the purpose of the Procurement Monitoring Bureau is to implement public administration functions in the supervision of procurements. The main functions of the Office are to monitor the compliance of procurements and concession procedures performed by the customers, public service providers, public partners and public partners with the requirements specified in regulatory enactments, as well as provide methodological support in the currying out of procurement procedures.

In Latvia, public procurement is regulated by the Public Procurement Law of 2017 (Public Procurement..., 2017). On March 1, 2017, the new Public Procurement Law entered into force, with significant improvements and amendments to include the requirements of Directives 2014/24/EU and 2014/25/EU.

The purpose of public procurement law is to guarantee the transparency of procurement, free competition among suppliers as well as equal and fair treatment of them, and also the efficient use of national and local government funding, maximally reducing the commissioning party's risks.

Public procurement should be considered as part of the economic system; therefore, the offer and price chosen as a result of the evaluation are closely linked to the development of the country. By focusing on the lowest price, which is the easiest and fastest way to choose a supply, so far, the second criterion for evaluating the most economically advantageous tender, and hence the issue of efficient procurement, has not been adequately researched. The role of competition in procurement and the factors that could facilitate it or, conversely, hinder it, as well as the role of the procurement commission in the preparation of tender documents and evaluation of tenders, have not been sufficiently studied (Skrastina, 2013).

Piening E.P (Piening, 2013) conducted that public sector organisations are facing unprecedented demands to become more efficient and effective against a backdrop of austerity, financial cutbacks and the rising demand for services. To address this, municipalities should make more use of the most economically advantageous tender criteria. Previous experience in Latvia shows that mostly the lowest price criterion is employed in evaluating bids in municipal public food procurement.

Previously, the Public Procurement Law stipulated that the contracting authority is free to choose the criterion for the winner of the procurement. The new Public Procurement Law defines the criterion of the most economically advantageous tender as the main criterion. The contracting authority determines it, taking into account the cost or price, the cost and quality criteria, or the price only. The law states that the contracting authority is still entitled to use the price only as a benchmark for the comparison and evaluation of offers provided the technical specifications are detailed and 
other criteria are not relevant to the selection of the offer. Unfortunately, this does not apply to "small procurements", where the estimated procurement contract price is 10000 Euro - 41999.99 Euro. In these procurements procurer still has the right to use the lowest price criterion.

The application of the most economically advantageous criterion is the way how it is possible to prefer local food producers in public food procurement. Such criteria can involve, for instance, price, quality, terms of delivery, life cycle cost or environmental values. The Law allows taking into account environmental issues, which enables the purchaser, i.e. the municipality to require short supply chain products.

\section{Green public procurement as one of the types of public procurement}

The European Commission defines GPP as a process in which public authorities try to procure goods, services and works whose environmental impact throughout their life cycle would be lower than for goods, services and works that have the same primary functions but which would have been acquired by applying different procurement principles (Buying green, 2016). In essence, it is a systematic integration of environmental criteria into all activities related to the procurement of goods or services, from defining needs, developing appropriate specifications and evaluating tenders to the monitoring of the results achieved.

According to the Treaty establishing the European Community, as well as the Latvian Public Procurement Law, procurers should ensure fair competition and equal treatment of all market participants. In order not to violate these principles, but in order to give preference to products from indigenous producers, local authorities should use the most economically advantageous criterion or, better, use of green public procurement criteria. Criteria such as delivery distance, the use of reusable packaging, favor local producers, but without excluding other potential tenderers from competition.

The goal of Green Public Procurement in Latvia is to ensure that purchases planned from the state budget and where are GPP criteria used by 2015 reach at least $15 \%$ in financial terms from the total procurement volume of state and local government institutions, in $201620 \%$ and in 2017 30\% (Green Public Procurement.., 2015).

In order to achieve these goals, as well as to promote the supply of local food products that has rapidly shrunk due to Russia's embargo on food products, in recent years several normative regulations have been adopted in Latvia in addition to the regulation of the public procurement law. These are Cabinet Instruction No. 5 of September 9,2014 "Guidelines for the Application of Green Public Procurement Criteria for the Catering Services an Food Procurement Performed by Public Authorities" (now expired) and Cabinet Regulation No 673 of October 28, 2014 "Regulations Regarding the Application of Environmental Criteria and the Definition of Choice Criteria for Food Offers" that expired with the entry into force of the new public procurement in March 2017.

Article 19 of the Public Procurement Law provides for a delegation to the Cabinet of Ministers to determine the principles of green public procurement, requirements and procedures for their application, criteria for evaluating the supply of goods, services and works that are subject to green public procurement requirements, the rules for the execution of procurement contracts and the control procedure.

As a result, on June 20, 2017, the Cabinet Regulation No. 353 " Requirements for Green Public Procurement and Procedures for their Application" (Requirements for green.., 2017) entered into force, which stipulates that a certain proportion of the foodstuffs supplied must be produced according to organic farming methods or be manufactured in accordance with the criteria of integrated production, or to meet the requirements of the National Food Quality Scheme. Similarly, the GPP provides that foods are free of genetically modified organisms, are not produced from them, are packaged in environmentally-friendly packaging and are delivered in an environmentally-friendly manner.

The GPP performers must ensure that the food supplied by the supplier meets these requirements and must verify the certificates provided by the supplier on the origin of the products and their compliance with organic farming. Although labour-intensive, but it is the lightest part of procurement, it is much more difficult for a customer to control the execution of a contract already concluded. The usual fraud scheme, which in some cases is implemented, is as follows: the supplier signs an intention with a biological farm for the delivery of certain products. And the certificate issued to the organic farmer for the origin of the products produced is submitted to the contracting authority. However, when the contract is concluded, the supplier does not actually buy products from the particular farm in reality, instead supplying cheaper, often foreign products that do not meet the green procurement criteria. Cabinet Regulations No.353 establishes a stronger control system, which allows one to hope that such cases in future practice will decrease.

\section{Characteristics of the public procurement situation in Latvia}

In Latvia, according to the data of Procurement Monitoring Bureau, the total public procurement amount for an average is 1.9 to 2.5 billion a year (see Figure 1 ).

Compared to 2015, there is a significant drop in not only GPP but also in total amounts of procurement of goods and services. In total, in 2016 there has been a drop in procurements in which the GPP criteria has been applied. When assessing the flows of various financial sources, it can be concluded that this has been affected by the process of implementation of EU fund projects, where, in 2015, procurement procedures for financing of projects of the previous EU-funded programming period were still carried out. To sum it up with the already launched procurement procedures within the framework of new 2014-2020 EU Funds programming period, this contributed to a significant increase in the share of GPP. In turn, given that in 2016 there was still intensive work on the development of a regulatory framework for the implementation of specific support objectives, there was a significant reduction in procurement volume. From this, it can be concluded that projects funded by EU funds make an important contribution to the growth of the share of GPP in the common procurement structure (Informative report.., 2017). 


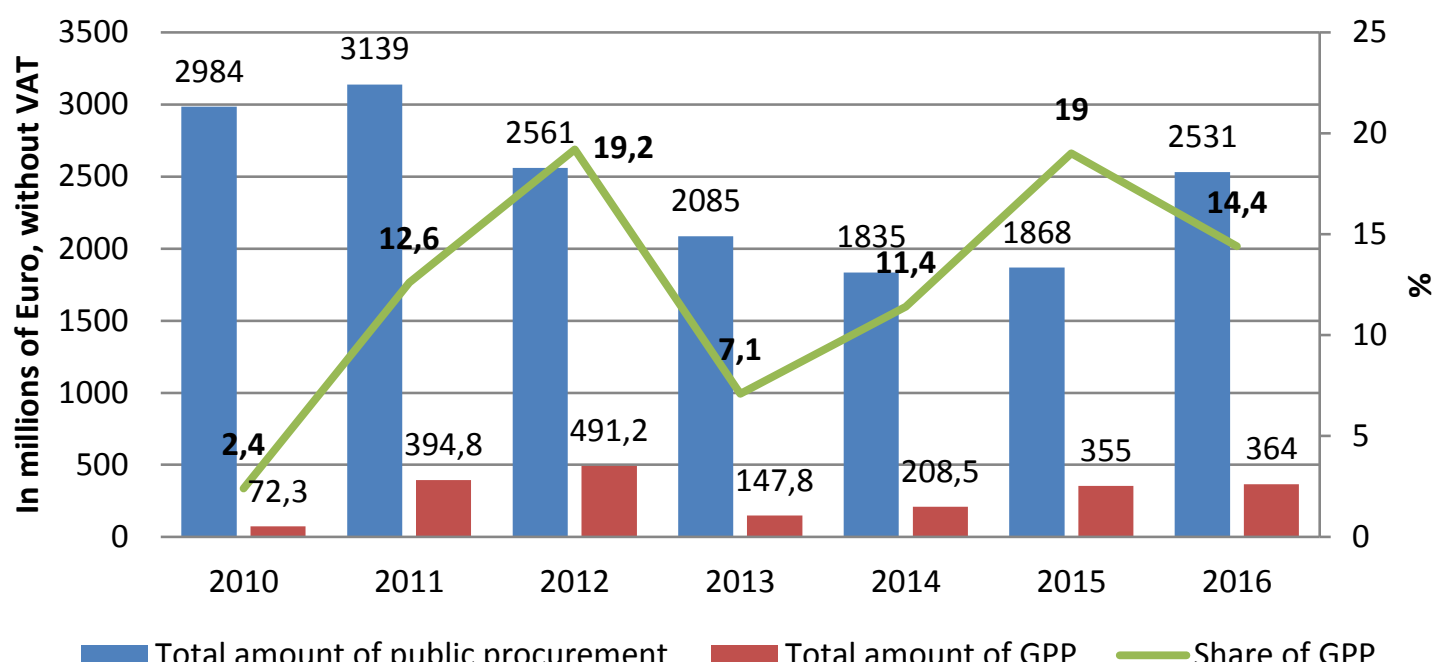

Figure 1. Dynamics of Public Procurement and Share of GPP in Latvia in 2010-2016 (Informative report.., 2017)

Taking into account the increase in the total amount of contracts, the publication of which refers to the use of criteria related to environmental protection requirements, it can be concluded that the target set in the Green Procurement Plan 2015-2017. - to ensure that in 2016 procurements which are planned from the state budget and in which there are GPP criteria applied, reach $20 \%$ in financial terms from the total amount of procurement by the state and local government authorities, has not been achieved. In financial terms it amounts only to $14.4 \%$. In the previous year, 2015, the target of $15 \%$ was reached and amounted to $19 \%$ (Informative report.., 2017).

There was a survey on the procurement of ten product/service groups in 2011 that shows that $26 \%$ of the last contracts signed by public authorities in the EU27 included all EU core GPP criteria. In addition, 55\% of these contracts included at least one EU core GPP criterion (Centre of European..., 2012). This means that much work is still needed in Latvia to bring it closer to the EU average.

The volume of public food procurement is reflected in Figure 2. Municipalities can choose two paths to provide clients of local authorities and pupils with the necessary food:

1) To carry out public food procurement;

2) To choose catering service procurement.

Figure 2 summarizes information on food procurement in Latvia.

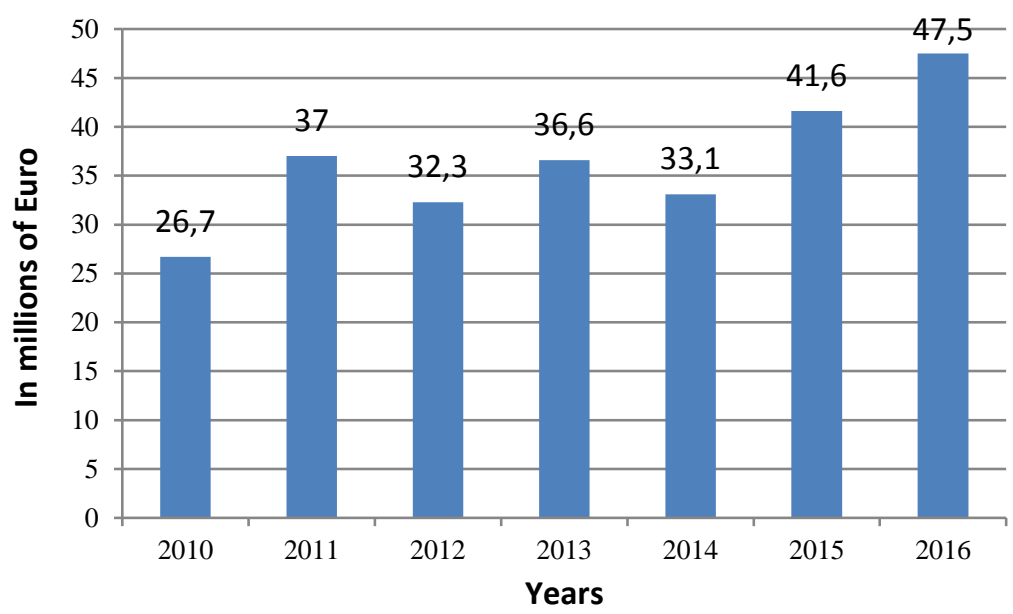

Figure 2. The dynamics of the volume of food procurement in Latvia in 2010-2016 (Authors construction, based on data of Procurement Monitoring Bureau, 2017)

In recent years, according to the PMB data, the total amount of public food procurement in Latvia exceeded EUR 40 million, and the amount tented to increase.

As mentioned above, Cabinet Regulation No. 673 "Regulations Regarding the Application of Environmental Criteria and the Definition of Choice Criteria for Food Offers" was in force from the end of 2014 to the beginning of 2017 therefore the Procurement Monitoring Bureau made a separate inventory of food procurements, which included environmental criteria in accordance with these Cabinet Regulations.

Data are shown in Table 1. 
Table1. Comparison of applicable environmental criteria in the public food procurement (Authors construction and calculations, based on data of Procurement Monitoring Bureau, 2017)

\begin{tabular}{|l|c|c|c|c|}
\hline & $\begin{array}{c}\text { Number of } \\
\text { procurers }\end{array}$ & $\begin{array}{c}\text { Number of contracts } \\
\text { concluded }\end{array}$ & $\begin{array}{c}\text { Total amount of contracts in } \\
\text { Euro (without VAT) }\end{array}$ & $\begin{array}{c}\text { Share of total food } \\
\text { procurement, } \%\end{array}$ \\
\hline 2015 & 123 & 304 & 2735395 & $6.6 \%$ \\
\hline 2016 & 142 & 403 & 4214262 & $8.9 \%$ \\
\hline $\begin{array}{l}\text { Growth rate (\%) against } \\
\text { the previous period }\end{array}$ & $15,4 \%$ & $32,6 \%$ & $54,1 \%$ & \\
\hline
\end{tabular}

As shown in Table 1, the number of procurements that included environmental criteria was upward trend and reaches $8.9 \%$ of all public food procurements in 2016. Probably the GPP criteria for food public procurement were used more often, but if in the procurement it was not indicated that the requirements of the relevant Cabinet Regulations were applied, these purchases were not counted separately.

It is not possible to precisely identify the proportion of local food in the mentioned amounts of public procurement, as the majority of contractors are wholesale companies that offer both local and non-local food products. However, having regard to the adoption of the above-mentioned Cabinet Regulations, some components of green public procurement are increasingly introduced (Krivasonoka and Zvirbule, 2016).

No studies have been conducted in Latvia on how winning local producers in procurement affects the number of jobs in the regions. The only major research carried out in 2015 was about the impact on the local government budget if the winner of the procurement is chosen not applying the lowest price, but the most economically advantageous tender criteria, which includes both the determination of the proportion of organic produce in the procurement and the distance from the producer to the consumer, and seasonality. The study explored one county of Latvia - Tukums county. The study concludes that if local food producers supply food to 10 local authorities (basically schools and kindergartens), which were previously done by wholesale bases, then the local government budget would directly increase by $6.26 \%$ through personal income tax payments. But, taking into account also the movement of money in the region and calculating the multiplier effect, the study concludes that, overall, the local government budget would increase by $19.85 \%$ (Korpa et al., 20115).

\section{CONCLUSIONS}

Public procurement plays an important role in the development of the regions. It is one of the market instruments to meet the needs of society and the efficient use of public funds. Therefore it is important to adjust the public procurement system in way to ensure that the use of funds of procurers and public service providers is respecting principles such as transparency, efficiency, fair competition and equal treatment of market participants. Therefore, in the EU Member States, including in Latvia, intensive work is underway to improve the normative acts in order to ensure the implementation of these criteria.

In Latvia, increasing attention is being paid to the GPP, which is promoted in various ways. Legislation has been adopted for certain groups of goods, including food products, in which the criteria of the GPP are included as mandatory. Including environmental requirements in public procurement (through green public procurement), it is possible not only to promote the growth of the share of environmentally friendly goods and services in the market, but also to achieve financial and social improvements, therefore it is important to develop these types of purchases as much as possible. The goal of Latvia for 2016 was that the GPP achieves at least $20 \%$ in financial terms from the total volume of procurement by the state and municipal authorities, in turn, in 2017, 30\%. When assessing the proportion of GPP in total purchases, it can be concluded that Latvia's target for 2016 has not been met, and the proportion of GPP was only $14.4 \%$.

Projects funded by EU funds make an important contribution to the growth of the share of GPP in the overall procurement structure. The presence or absence of EU fund projects has a significant impact on the total public procurement volume in the country as well as on the volume of GPI.

In recent years the total amount of public food procurement in Latvia exceeded EUR 40 million, and the amount tented to increase.

The number of procurements that included environmental criteria is also upward trend and reaches $8.9 \%$ of all public food procurements in 2016. However, it is also less in the relevant product group than the national target, with $20 \%$ of the procurement being GPP.

\section{REFERENCES}

1. Adams, D.C., Salois, M.J. 2010. Local versus organic: a turn in consumer preferences and willingness-to-pay. Renewable Agriculture and Food Systems, Vol. 5(4), pp. 331-341. https://doi.org/10.1017/S1742170510000219

2. Buying green. 2016. A handbook on green public procurement, 3rd Edition. Available at http://ec.europa.eu/environment/gpp/pdf/handbook.pdf (Accessed 12/11/2017)

3. Centre of European Policy Studies. 2012. The Uptake of Green Public Procurement in the EU27. Study. Available at http://ec.europa.eu/environment/gpp/pdf/CEPS-CoE-GPP\%20MAIN\%20REPORT.pdf (Accessed on 18/02/2018)

4. Going green: best practices for green procurement - PORTUGAL. 2014. OECD report. Available at https://www.oecd.org/governance/procurement/toolbox/search/portugal-best-practices-green-public-procurement-gpp-awarenessraising.pdf (Accessed on 04/11/2017) 
5. Green Public Procurement Support Plan 2015-2017. 2015. Cabinet Order No.83. Available at https://likumi.lv/ta/id/272295-parzala-iepirkuma-veicinasanas-planu-2015-2017-gadam (Assessed on 21/09/2017)

6. Informative Report on the Green Public Procurement Support Plan 2015-2017 progress in 2016. 2017. Report. Available at http://www.varam.gov.lv/in_site/tools/download.php?file=files/text/Darb_jomas/ZPI//VARAMZINO_120516_ZPI_2015.pdf (Accessed on 05/11/2017)

7. Jackson, M. 2010. Making the Most of Public Sector Spend: Procurement as Local Economic Activism. Briefing of Centre for Local Economic Strategies. Briefing. Available at http://www.cles.org.uk/wp-content/uploads/2011/01/Procurement-as-localeconomic-activism.pdf (Accessed on 12/09/2017)

8. Knight, A.J. 2011. Evaluating Local Food Programs: The Case of Select Nova Scotia. Evaluation and Program Planning, Vol. 36, Iss. 1, pp. 29-39.

9. Korpa, V., Silina, L., Sulce G. 2015. Increasing the share of local producers in local government food procurements: analysis of the situation in Tukums district. Available at http://new.llkc.lv/system/files force/aktualitates/petijums.pdf?download=1 (Accessed on 18/02/2018)

10. Krivasonoka I., Zvirbule A. 2016. Role of Municipalities in Local Food Distribution in Latvia. Proceedings of the 2016 International Scientific Conference Economic Science for Rural Development, No 41, pp. 96-103, Latvia University of Agriculture, Jelgava

11. Manzini R., Accorsi R. 2012 The New Conceptual Framework for Food Supply Chain Assessment. Journal of Food Engineering, Vol. 115 (2013), pp. 251-263. https://doi.org/10.1016/j.jfoodeng.2012.10.026

12. Piening, E.P. 2013. Dynamic capabilities in public organizations: a literature review and research agenda. Public Management Review, Vol.15, pp. 209-245. https://doi.org/10.1080/14719037.2012.708358

13. Pringle, A. 2013. The Power of Purchasing: The Economic Impacts of Local Procurement. Research report. Available at http://locobc.com/wp-content/uploads/Local_Procurement_FinalforWeb.pdf. (Accessed on 24/03/2017)

14. Procurement Monitoring Bureau Statute.2013. Cabinet Regulations. Available at https://likumi.lv/doc.php?id=95643 (Accessed on 11/10/2017)

15. Procurement Monitoring Bureau. 2017. Statistical data. Available at https://www.iub.gov.lv/lv/node/184 (Accessed on 06/10/2017)

16. Public Procurement Law. 2017. Law of the Republic of Latvia. Available at https://likumi.lv/doc.php?id=287760 (Accessed on 11/10/2017)

17. Requirements for green public procurement and the procedure for their application. 2017. Cabinet Regulations No.353. Available at https://likumi.lv/doc.php?id=291867 (Accessed on 06/10/2017)

18. Russell, C., Meehan, J. 2014. Exploring legitimacy in major public procurement projects. Public Procure, Vol. 14, pp.419-461.

19. Skrastina, U. 2013. Contract award criteria and evaluation of tenders in public procurement. Doctoral dissertation, University Turiba.

20. Tewes-Gradl, C., Peters, A., Vohla, K., Lutjens-Schilling, Lena. 2013. Inclusive Business Policies: How Governments Can Engage Companies in Meeting Development Goals. Available at http://www.endeva.org/wpcontent/uploads/2014/11/Endeva_IBPolicies_2013-2.pdf (Accessed on 04/11/2017)

21. What is GPP. 2014. EU information. Available at http://ec.europa.eu/environment/gpp/what_en.htm (Accessed 29/09/2017) 